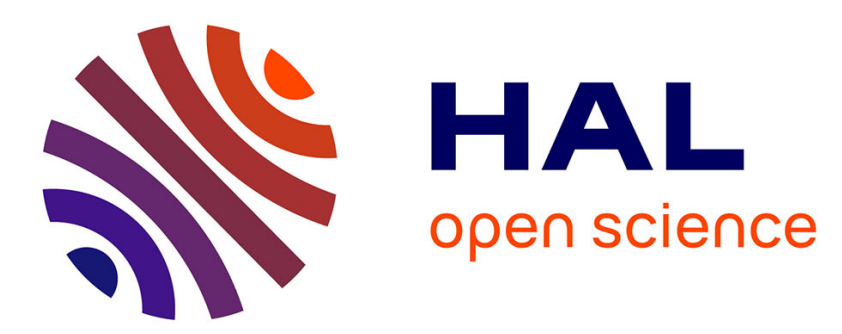

\title{
Effect of initial physical characteristics on sludge compost performance
}

\author{
A. Trémier, C. Teglia, S. Barrington
}

\section{To cite this version:}

A. Trémier, C. Teglia, S. Barrington. Effect of initial physical characteristics on sludge compost performance. Bioresource Technology, 2009, 100 (15), p. 3751 - p. 3758. 10.1016/j.biortech.2009.01.009 . hal-00455552

\section{HAL Id: hal-00455552 https://hal.science/hal-00455552}

Submitted on 22 Feb 2010

HAL is a multi-disciplinary open access archive for the deposit and dissemination of scientific research documents, whether they are published or not. The documents may come from teaching and research institutions in France or abroad, or from public or private research centers.
L'archive ouverte pluridisciplinaire HAL, est destinée au dépôt et à la diffusion de documents scientifiques de niveau recherche, publiés ou non, émanant des établissements d'enseignement et de recherche français ou étrangers, des laboratoires publics ou privés. 
Effect of initial physical characteristics on sludge compost performance Anne Trémier ${ }^{1,2,}$, Cécile Teglia ${ }^{1,2,}$ Suzelle Barrington ${ }^{3}$

${ }^{1}$ Cemagref, UR GERE, 17 avenue de Cucillé, CS 64427, F-35044 Rennes, France

${ }^{2}$ Université Européenne de Bretagne, F-35000 Rennes, France

${ }^{3}$ Macdonald Campus of McGill University, 21111 Lakeshore, Ste Anne de

Bellevue, Canada H9X 3V9

Corresponding author: Anne Tremier, Ph. D.,

Cemagref UR GERE, 17 avenue de Cucillé, CS 64427, F-35044 Rennes Cedex France

Tel.: +00332234821 21; fax: +0033223482115.

E-mail: anne.tremier@cemagref.fr

Article: Special Issue WasteEng08

Submitted to the journal: Bioresource Technology 


\section{Abstract}

To develop an active microbial activity quickly developing stabilizing thermophilic temperatures during the composting of wastewater sludge, the bulking agent (BA) plays a major role in establishing the recipe structure, exposed particle surface area and porosity. To optimize the biodegradation of a sludge compost recipe, the objective of this paper was to study the effect and interaction of initial moisture content (MC) and BA particle size distribution. Three $300 \mathrm{~L}$ insulated laboratory composters were used to treat two series of ten (10) recipes with different combinations of $\mathrm{MC}$ and $\mathrm{BA}$ particle size distribution. Using a BA to wastewater sludge dry mass ratio of $1 / 6$, the ten (10) recipes were repeated using two BA, residues recycled from a commercial sludge composting plant and crushed wood pallets. Each four week trial monitored $\mathrm{O}_{2}$ uptake, temperature, compost consolidation and airflow distribution. The Central Composite Factor Design method produced a model from the results estimating the impact of a wider range of $\mathrm{MC}$ and $\mathrm{BA}$ particles size distribution. The $\mathrm{MC}$ directly affected the total $\mathrm{O}_{2}$ uptake and therefore organic matter biodegradation. The BA particle size distribution influenced compost consolidation with a MC crossed effect. Both BA particle size distribution and MC influenced compost airflow dispersion. Composting was optimized using the BA consisting of recycled green waste residues with particle size of 20 to $30 \mathrm{~mm}$ and a $55 \% \mathrm{MC}$. The predictive models suggested the need for further optimization of sludge and wood residue composting recipe.

Keywords: sludge, bulking agent, composting, physical characteristics. 


\section{Introduction}

The European Community is advocating principles of prevention, recycling and reuse to reduce the environmental and social issues associated with the landfilling of organic wastes (Parlement Européen and Conseil, 2006). In this context, biological treatments such as composting are promoted to transform organic wastes into soil amendments. Nevertheless and for wastewater sludge, environmental advantages must be demonstrated to justify expensive composting infrastructures. The quality of the finished product requires stabilization and sanitization, components highly dependent on microbial activity especially at the onset of the process (Miller, 1991).

Optimal aerobic microbial activity is developed as a result of three main conditions: (1) accessible biodegradable organic matter; (2) aerobic conditions maintained throughout the mass, and; (3) chemical and physical conditions conducive to microbial development, such as optimal $\mathrm{pH}, \mathrm{C}: \mathrm{N}$ ratio, moisture content (MC) and temperature. The compost recipe must be formulated based on the properties of the waste to be treated such as: its biodegradability, particle size exposing a specific surface area and porosity; the nature of the aeration system, namely static, passive or dynamic, and; the turning frequency of the compost (Barrington et al., 2002). A specific composting process is influenced by the nature of the treated waste, and specifically its physical characteristics (Agnew and Leonard, 2003).

Numerous studies have measured the biodegradable potential of organic wastes through chemical or biochemical measurements, but few have investigated the effect of physical parameters on the biodegradability of the compost material. Physical characteristics play a major role in determining $\mathrm{O}_{2}$ distribution and microbial access to biodegradable organic matter. Based on their impact, the physical characteristics of compost can be classified into five (5) categories: moisture content (MC); density; 
particle size distribution; air porosity, and; air distribution throughout the compost (Agnew and Leonard, 2003). According to Kraft (2002), two more parameters affect gas flux, namely specific surface area of the compost particles and air permeability. Indeed, microbial growth depends on MC because water for example, is a reactant during hydrolysis. Nevertheless, MC must not limit the transfer of gases such as $\mathrm{O}_{2}$ and $\mathrm{CO}_{2}$ (Miller, 1991 ; Aguilar-Juarez, 2000). Compost consolidation influences density and as a consequence, aeration and gas exchanges. Particle size distribution defines the particle surface exposed to microbial biodegradation (Mohee and Mudhoo, 2005) and the compost consolidation potential. By acting on permeability, air porosity influences airflow pathways (Veeken et al., 2003) and therefore biodegradation kinetics through heat and gas transfers (Agnew and Leonard, 2003). Lastly, particle size distribution and air porosity define the tortuosity factor, namely the ratio between real and linear airflow pathways, which impacts the effective dispersion of air (Coulson and Richardson, 1994). For a successful composting process, these physical characteristics must be managed to quickly produce thermophilic temperatures. The MC can be optimized by adding water or a dry bulking agent (BA). Specific surface area and air porosity can be modified by selecting the proper BA particle size distribution and waste to $\mathrm{BA}$ ratio.

When composted, wastewater sludge offers no structure and a high MC, thus, requiring a very specific BA particle size distribution and mass ratio. Eftoda and McCartney (2004) studied BA requirements to optimize the free air space (FAS) value of sludge composted with wood chips. Gea et al. (2007) are among the few who studied the individual effect of BA particle size distribution and mass ratio on sludge compost behaviour $\left(\mathrm{O}_{2}\right.$ uptake, consolidation, airflow patterns $)$, but the interaction between MC and BA particle size distribution was not investigated. 
Therefore, the objective of this project was to study the impact and interaction of initial MC and BA particle size distribution on compost material biodegradability. Two different BA were tested: BA1 consisting of green wastes recycled from a commercial sludge composting plant, and; BA2 consisting of crushed wood pallets. The study was conducted using three laboratory composters, each with a $300 \mathrm{~L}$ working volume. The final objective was to optimize the composting of sludge with wood residues, and ensure its complete and fast stabilization.

\section{Materials and Methods}

\subsection{Composting reactor and monitoring instruments}

The composting of sludge and BA was studied using three pilot reactors (Figure 1) simulating the active phase of the composting process (De Guardia et al., 2008). Each reactor consisted of an airtight $300 \mathrm{~L}$ stainless steel cylindrical chamber with an inside diameter of $0.7 \mathrm{~m}$ and a length of $0.8 \mathrm{~m}$. A $50 \mathrm{~mm}$ layer of polyurethane insulated the reacting chamber and limited heat losses. Aeration was provided by an air blower introducing air through the bottom plenum of the reactor, at a continuous rate of 550L $\mathrm{h}^{-1}$. Gas samples were collected for analysis from the top plenum.

Parameters monitored during the experiments were: air flow rate as measured by a volumetric air flow meter (Actaris, France, Gallus G 1.6, $\mathrm{Q}_{\max }$ of $2.5 \mathrm{~m}^{3} \mathrm{~h}^{-1}$ ), mass loss using a continuous mass monitoring device (Precia Molern, France) on each reactor, temperature of the compost using Pt 100 temperature probes (TC SA France, thermocouple $\mathrm{K}$ ), inlet and outlet air temperature and relative humidity (Vaisala, France, HMP 243, 0-100\%/0-100\%), depth of the compost inside the reactor (manually), and inlet and outlet air stream $\mathrm{O}_{2}$ concentration using a paramagnetic analyser (Servomex, France, Analyser 4200, 0-25\% $\mathrm{O}_{2}$ ). 
Moreover, the airflow pathway was characterized using a gas tracing method determining the Retention Time Distribution (RTD) and the airflow dispersion coefficient (D') within the reactors (Tremier et al., 2005). Methane was chosen as tracer because of its detection in limited concentrations of less than 50ppm at the outlet of the reactors and it lack of impact on the microorganisms involved in the composting process. Also, methane offers gas properties similar to those of air and it is easily quantified using an infrared detector. For each RTD measurements, $150 \mathrm{ml}$ of tracer gas (methane) were injected as a pulse into the entering airstream using a $150 \mathrm{ml}$ syringe. The concentration of tracer gas at the reactor airstream exit was monitored every minute using an infrared detector (Servomex, France, Analyser 4200, $\mathrm{CH}_{4}$ of 0 $10 \%)$ until its volume was almost completely recovered. The RTD curve $(\mathrm{E}(\mathrm{t}))$, the mean residence time $(\bar{t})$ and the variance $\left(\sigma^{2}\right)$ were computed from the measured tracer gas concentration and air stream flow rate (Levenspiel, 1999).

All three compost pilot reactors were used during the study to test each composting recipe for four (4) weeks and the compost material was turned once, early in the third weeks of composting.

\subsection{Experimental materials}

The experimental dewatered sludge was obtained from an activated sludge reactor treating the wastewaters of a slaughterhouse. The two experimental bulking agents were: BA1 composed of green wastes recycled from a commercial plant composting slaughter house sludge, and; BA2 consisting of crushed wood pallets. As opposed to BA1, BA2 consisted of relatively inert organic matter carrying a limited microbial population adapted to composting. All mixtures composed of BA1 and BA2 were called M1 and M2, respectively. Both M1 and M2 had the same BA to sludge dry mass 
ratio of $1 / 6$, to compare recipes with the same potential organic matter biodegradability. Thus, composting behaviour for each trial, such as $\mathrm{O}_{2}$ uptake and loss of mass, was mostly affected by its physical characteristics.

\subsection{Experimental design}

For composting and to study the influence of the initial $\mathrm{MC}$ and $\mathrm{BA}$ particle size distribution, the statistical procedure consisted of setting up a Central Composite Factor Design. This design produces a second order polynomial equation or model (Goupy, 1999). Using the two independent variables, namely MC and BA particle size distribution, two series of ten (10) experiments were conducted where, for each series, four (4) experimental points corresponded to a two factors complete factorial design, two (2) points offered central values and four points offered extreme values ( $\alpha=$ 1.414). Thus, five values were tested for each independent variable: $\mathrm{MC}$ in the range of 20 and $70 \%$, and; BA particle size distribution in the range of 8 and $>40 \mathrm{~mm}$. For each type of BA, five (5) particle size distributions were obtained using a rotary sieve and then dried. The experimental MC was obtained by either adding water or partially drying the sludge for a few days at $30^{\circ} \mathrm{C}$. Table 1 summarizes the experimental conditions tested using a set of ten (10) trials for each type of BA. To conduct the statistical analysis, the values for both independent variables were normalized (Table $1)$.

\subsection{Statistical analysis}

The Central Composite Factor Design uses the following second-order polynomial model to predict the composting behaviour of a large number of combinations for 
various MC and BA particle size distribution, based on the results obtained from each set of ten (10) experimental trials:

$$
y=\beta_{0}+\beta_{1} x_{1}+\beta_{2} x_{2}+\beta_{3} x_{12}+\beta_{4} x_{11}+\beta_{5} x_{22}
$$

where $y$ is the predictive response $\left(\mathrm{O}_{2}\right.$ uptake; compost consolidation and airflow dispersion), $\mathrm{x}_{1}$ and $\mathrm{x}_{2}$ are the normalized independent variables, $\mathrm{x}_{12}$ is the interaction between the independent variables, $x_{11}$ and $x_{22}$ are the quadratic interactions of the independent variables and $\beta_{\mathrm{i}}$ are the model coefficients. Separate models were produced for M1 and M2.

Analysis of variance (ANOVA) determined the significance of the models using the F-Test, at a confidence level of $90 \%(\mathrm{p}<0.1)$. Moreover, the significance of each regression model parameter (variable or interaction) was determined using a Student Test at a confidence level of $75 \%(\mathrm{p}<0.25)$. Such low confidence level is justified by the model coefficients $\left(\beta_{\mathrm{i}}\right)$ which were larger than the determination error of their respective values, where this determination error is related to the experimental error. In this study, the heterogeneous substrate led to relatively large standard deviations ranging from 10 to $20 \%$. Therefore a confidence level of $75 \%$ rather than $90 \%$ was considered to be significant, considering that $90 \%$ could not be obtained.

The regression coefficient $\mathrm{R}^{2}$ measured the global fit of the regression model with the experimental data and the adjustment of the models was considered acceptable for $\mathrm{R}^{2}$ greater than $55 \%$. All statistical analyses were performed with the software Statgraphics (Centurion XV, Warrentown, Virginia, USA).

\subsection{Chemical analysis}

All experimental materials and compost mixtures were analyzed for dry matter (DM, \%), organic matter (OM , \% DM), Total Carbon (TC, mg C g DM${ }^{-1}$ ), Chemical 
Oxygen Demand (COD, $\mathrm{mg} \mathrm{O}_{2} \mathrm{~g} \mathrm{DM}^{-1}$ ) and Total Kjeldhal Nitrogen (TKN, mg N g $\left.\mathrm{DM}^{-1}\right)$.

Dry matter was obtained by drying triplicate wet samples of $1 \mathrm{~kg}$ at $80^{\circ} \mathrm{C}$ until a constant mass was reached. Moisture content (MC) was determined as the difference between the wet and dry masses. Organic matter (OM) was determined by incinerating dried samples at $550^{\circ} \mathrm{C}$ for 4 hours (Standard method NF U 44-160, Afnor, 1985).

Total Carbon (mg C $\mathrm{g} \mathrm{DM}^{-1}$ ) was determined according to the standardised method NF-EN-13137 (Afnor, 2001a) where dried samples are oxidised to $\mathrm{CO}_{2}$ quantified by infrared spectrometry (SKALAR device, The Netherlands, Formacs TOC Analyser). Chemical Oxygen Demand (COD) was determined by dichromate oxidation on dried $50 \mathrm{mg}$ samples (adaptation of the standard method NF T 90-101, Afnor, 2001b). Total Kjeldahl Nitrogen was determined using dried $50 \mathrm{mg}$ samples mineralized using $18 \mathrm{M}$ sulphuric acid, followed by steam distillation and then titration (adaptation of the standard method NF ISO 11261, Afnor, 2000).

\section{Results and discussion}

\subsection{Chemical characteristics of the substrates and mixtures}

All experimental materials and compost mixtures M1 and M2 are characterized in Table 2. With a coefficient of variation $(\mathrm{CV})$ under $10 \%$, where $\mathrm{CV}$ is defined as the standard deviation divided by the mean value, the sludge and BA samples offered similar OM and TC. The sludge and the two bulking agents, BA1 and BA2, offered an average OM to TC ratio of 1.66, 1.81 and 20.5 respectively, while the M1 and M2 mixtures offered a ratio of 1.81 and 1.96. These values are in the range of the typical ratio of 1.83 commonly used to compute TC from the OM of organic wastes (Barrington et al., 2002). 
The Total Kjeldahl Nitrogen (TKN) values were more variable especially for the various particle size distributions for both BA1 and BA2, because: the analytical samples limited to $50 \mathrm{mg}$ are relatively small compared to the BA particle size; sieving the BA to obtain a specific particle size distribution likely lead to variation, and; drying the BAs before analysis lead to some $\mathrm{N}$ volatilization.

The M1 and M2 mixtures demonstrated a low CV under 5\% for all parameters except for TKN (CV over 25\%) which reflected the variability of this parameter with particle size distributions for both BA1 and BA2. Nevertheless, individual M1 and M2 mixtures were considered equivalent because their $\mathrm{C}: \mathrm{N}$ ratio remaining within a similar respective range of $15+/-5$ and $38+/-9$, for all particle size distributions. Thus, individual M1 and M2 mixtures offered comparable chemical characteristics and total potential biodegradable organic matter. Thus, for a given mixture for M1 or M2, the observed differences in the composting behaviour were attributed to the physical characteristics, namely MC and BA particle size distribution.

\subsection{Composting behaviour of the recipes}

All compost recipes were monitored for biodegradation, characterized by total $\mathrm{O}_{2}$ uptake, temperature regime, consolidation or change in depth of the material inside the reactor, and air dispersion coefficient indicating the variation in airflow dispersion.

The biodegradability of the compost mixtures is reflected by the initial $\mathrm{O}_{2}$ uptake rate peaking after 2 to 5 days, depending on the recipe (Figure 2). Temperature varied in parallel with $\mathrm{O}_{2}$ uptake rate. By the end of week two, the $\mathrm{O}_{2}$ uptake rate and temperature had dropped to a low stable value. All compost mixtures were then remixed which generated another shorter and smaller peak resulting from renewed microbial activity. The second peak was more pronounced for the M1 trials as compared to those for M2. 
For both $\mathrm{M} 1$ and $\mathrm{M} 2$ trials, peak temperature and $\mathrm{O}_{2}$ uptake rate and time to reach these peaks were observed to vary with MC but not with BA particle size distribution. The highest peak $\mathrm{O}_{2}$ uptake rates were obtained with $45 \% \mathrm{MC}$.

For the M1 mixtures, an initial MC of $63 \%$ waterlogged the recipes for trials 3 and 10, resulting in a low $\mathrm{O}_{2}$ uptake because of limited compost aeration. For trial 3, the $\mathrm{O}_{2}$ uptake rate increased during the first three (3) days but peaked at only $10 \mathrm{mMol} \mathrm{O}_{2} \mathrm{~h}^{-1}$ $\mathrm{kg} \mathrm{DM}^{-1}$ and remained at that level thereafter. For trial 10 , the $\mathrm{O}_{2}$ uptake rate increased slowly to peak after 12 days at $12 \mathrm{mMol} \mathrm{O}_{2} \mathrm{~h}^{-1} \mathrm{~kg} \mathrm{DM}^{-1}$. As compared to $\mathrm{M} 1$ for trials 3 and 10, the M2 mixtures showed no water logging and no atypical $\mathrm{O}_{2}$ uptake rate likely because BA2, consisting of crushed wood pallets, had a higher water absorption capacity, as compared to BA1.

With mixtures M1 and M2, respectively, temperatures peaked between 43 to $60{ }^{\circ} \mathrm{C}$, and 35 to $60{ }^{\circ} \mathrm{C}$, with mean temperatures consistently higher with the M1 mixtures. Similarly, the M1 mixtures demonstrated a higher total $\mathrm{O}_{2}$ uptake of 3.1 to $10.5 \mathrm{~mol} \mathrm{O}_{2}$ $\mathrm{kg} \mathrm{DM}^{-1}$ as compared to those of $\mathrm{M} 2$ of 1.6 to $7.8 \mathrm{~mol} \mathrm{O}_{2} \mathrm{~kg} \mathrm{DM}^{-1}$. Already carrying a microbial population adapted to sludge composting, M1 mixtures with BA1 lead to a more extensive organic matter biodegradation as compared to M2 mixtures with BA2.

Compost consolidation or change in compost material depth inside the reactor differed based on the type of BA used, but not among trials for individual BA. Most of the consolidation occurred during the first five (5) days of composting, as was also observed by Yue et al. (2008) composting sludge with bark and cornstalk.

Consolidation was more important for the M1 mixtures losing 0.4 to $15 \%$ of their initial depth, as compared to the M2 mixtures losing 0 to $7.9 \%$. After the mixing operation conducted early in week three, more consolidation was observed especially 
with the M1 mixtures which also developed a second peak in microbial activity surpassing those of mixtures M2.

The Retention Time Distribution (RTD) curves present airflow patterns throughout the composting medium (Figure 3). For all ten (10) trials, RTD curves did not show peaks suggesting that stagnant zones were basically absent and aeration short-circuiting did not occur. The RTD curves produced no thin symmetrical peaks associated with plug flow, nor exponentially decreasing curves associated with mixed flow (Levenspiel, 1999). Accordingly, airflow distribution respected an intermediate plug flow pattern with some dispersion. However, the extent of dispersion varied from one trial to the other, based on the BA particle size distribution and the added effect of MC.

Based on the measured data, a compartment flow model including a dispersion term was proposed to simulate the experimental RTD curves and to determine the global dispersion coefficient according to the method proposed by Tremier et al. (2005). The dispersion coefficient determined at the beginning of the composting trials was always higher for mixtures M2 as compared to mixtures M1 (Figure 3). Thus, the aeration conditions seemed to induce more homogeneity with BA2 as compared to BA1.

In summary, mixtures M1 and M2 demonstrated similar general composting behaviours. Nevertheless, quantitative differences were measured between each trial and type of BA, leading to different levels of biodegradation and physical behaviour. Firstly, BA2 consisting of crushed wood pallets, demonstrated a higher water absorbing capacity and allowed for adequate aeration even at $\mathrm{MC}$ above $60 \%$, as opposed to BA1 consisting of recycled green residues. Secondly, BA1 resulted in a higher temperature regime and a higher cumulative and rate of $\mathrm{O}_{2}$ uptake, indicating a greater level of organic matter biodegradation. Bulking agent BA2 consisting of crushed wood pallets, was more inert and carried less microbes adapted to sludge 
composting. Finally, mixtures M2 resulted in less consolidation and more aeration dispersion. The uniform aeration conditions lead to a more homogeneous biodegradation of the organic waste, explaining the limited microbial activity of the M2 mixtures after the mixing operation of week three.

\subsection{Influence of the initial physical parameters}

All compost recipes had the same dry mass ratio of BA to sludge and thus offered the same level of potential organic matter biodegradation. Nevertheless, the total or cumulative $\mathrm{O}_{2}$ uptake differed from one trial to another (Table 3) as well as the relative consolidation and the initial airflow dispersion coefficient. The effect of MC and BA particle size distribution significantly influencing $\mathrm{O}_{2}$ uptake, consolidation and air dispersion.

\subsubsection{Predictive $\mathrm{O}_{2}$ uptake}

The Central Composite Factor Design method produced the following predictive responses $\mathrm{O}_{2}$ uptake for mixtures $\mathrm{M} 1$ and $\mathrm{M} 2$ :

$$
\begin{aligned}
& \text { Cumulative } \mathrm{O}_{2(\mathrm{M} 1)}=8.322-3.622 * \mathrm{X}_{11} \\
& \text { Cumulative } \mathrm{O}_{2(\mathrm{M} 2)}=5.521+1.978 * \mathrm{X}_{1}-1.371 * \mathrm{X}_{11}
\end{aligned}
$$

These correlations are highly significant as demonstrated by $\mathrm{F}$ values obtained with ANOVA (Tables 4 and 5). The predictive power of Equation (3) for the M2 mixtures was higher with an $\mathrm{R}^{2}$ of $78 \%$, as compared to that of Equation (2) with the M1 mixtures, with an $\mathrm{R}^{2}$ of $60 \%$.

For both M1 and M2 mixtures, only MC significantly and positively influenced $\mathrm{O}_{2}$ uptake. The quadratic effect defines an optimum $\mathrm{MC}$ over which $\mathrm{O}_{2}$ uptake decreases. The observed correlation agreed with the results of Liang et al. (2003) composting 
sludge, and Richard et al. (2002) and Ahn et al. (2008) composting other substrates such as straw or manure. All these studies found MC to positively influence organic waste biodegradation at values of 50 to $60 \%$ (w.w.). The predictive values obtained with Equations 2 and 3, as illustrated in Figures 4 and 5, suggest an optimum MC in the range of $50 \%$ for mixture M1 and $72 \%$ for mixture M2. Accordingly, BA2 consisting of crushed wood pallets offered a greater water absorption capacity as compared to BA1 consisting of green waste recycled from the commercial composting plant. With BA1, water logging eliminated the beneficial microbial effects of water at high MC levels.

\subsubsection{Compost consolidation}

Mixture consolidation was influenced by MC and BA particle size distribution. The positive coefficients (Table 4) show that as MC increased so did consolidation along with biodegradation. Nevertheless, the effect of MC was balanced by the effect of BA particle size distribution $(\mathrm{p}<0.2)$, because larger particles limited consolidation.

Table 4 shows that the predictive response curves for consolidation were successfully modelled for both M1 and M2 ( $<<0.1)$, but Tables 5a and b show that the adjustment of the model was good for $\mathrm{M} 1\left(\mathrm{R}^{2}=87 \%\right)$ but poor for $\mathrm{M} 2\left(\mathrm{R}^{2}=51 \%\right)$. Accordingly, the regression model could not be used to predict consolidation for M2 mixtures. For M1, the model took into account the quadratic effect of each independent variable, namely $\mathrm{MC}$ and $\mathrm{BA}$ particle size distribution and their interaction. The model also assessed their crossed influence on consolidation and defined conditions for the highest consolidation level corresponding to a MC of $60 \%$ and BA particle size of 30 $\mathrm{mm}$. To promote good composting conditions (biodegradation and aeration) this configuration must be avoided. 


\subsubsection{Airflow dispersion coefficient}

For the M1 mixtures, the initial airflow dispersion coefficient was mostly influenced by $\mathrm{MC}$ and BA particle size distribution, and their squared or crossed interaction (p <0.10; Table 4). The MC and BA particle size distribution had reverse effects, since a higher MC limited air porosity especially at values of 50 to $60 \%$, while a higher BA particle size distribution increased porosity when optimized at 20 to $30 \mathrm{~mm}$. The predictive regression model was validated $(\mathrm{p}<0.05)$ and presented a good fit with the experimental data $\left(R^{2}=96\right.$; Table $\left.5 a\right)$. For mixtures M1, Figure 6 shows the estimated response surface for the global dispersion coefficient.

High airflow dispersion leads to homogeneous $\mathrm{O}_{2}$ distribution and optimal composting conditions. For the M1 mixtures, high dispersion corresponded to a low MC and large particle size distribution (Figure 6), but this combination did not optimize organic matter degradation and microbial activity as characterized by a lower $\mathrm{O}_{2}$ uptake. Intermediate values must therefore be found to improve the selection of these parameters.

No conclusions could be drawn for the M2 mixtures, despite the initial airflow dispersion coefficient influenced by the quadratic interaction between MC and BA particle size distribution (Table 4). The CV for the airflow dispersion coefficient was very large, explaining why the predictive model did not fit the data adequately $(\mathrm{p}>$ 0.1). For trials 1 and 9 with similar recipes for examples, the $\mathrm{D}^{\prime}$ values offered a $\mathrm{CV}$ of $97 \%$. More experimental points were needed with the M2 mixtures to decrease the error and increase the degree of freedom.

\subsubsection{Optimizing the characteristics of the M1 mixtures}


Three objectives must be achieved to optimize the treatment of sludge composted with wood residues. Firstly, organic matter biodegradation characterized by a high $\mathrm{O}_{2}$ uptake rate must be promoted to obtain the desired stabilization effect. Secondly, mixture consolidation during composting must be minimized to promote $\mathrm{O}_{2}$ dispersion and reduce anaerobic zones releasing odours and greenhouse gases such as methane and nitrous oxide. Thirdly, the structure of the mixture must ensure a high airflow dispersion coefficient for a homogeneous composting process. For the tested sludge/BA dry mass ratio of $1 / 6$, such conditions correspond to a MC of $55 \%$ and a BA particle size distribution of $20-30 \mathrm{~mm}$.

\section{Conclusions}

The objective of the project was to study the effect on wastewater sludge composting efficiency of moisture content (MC) and bulking agent (BA) particle size distribution. The results show that increasing MC up to an optimum level improved organic matter biodegradation. Beyond this optimum MC value, water negatively affected aeration and microbial $\mathrm{O}_{2}$ supply. Influencing aeration, compost consolidation was limited by reducing MC and increasing BA particle size distribution. Airflow dispersion and as a consequence, aeration homogeneity was improved with a low MC and a large BA particle size distribution.

Using the Central Composite Design method, empirical models were produced and validated to optimize composting recipes. Accordingly and for the mixtures using recycled green waste residues as $\mathrm{BA}$, the best composting performance was obtained with a $55 \% \mathrm{MC}$ and a BA particle size distribution of 20 to $30 \mathrm{~mm}$. Moreover, this type of BA proved to have a quantitative effect on composting behaviour. The green waste residues recycled from a commercial composting plant, namely BA1, increased 
organic matter biodegradability as compared to crushed wood pallets or BA2, but offered less moisture absorption capacity. Crushed wood pallets as BA2 produced less consolidation and a higher airflow dispersion. Further studies are required to optimize the ratio of each respective BA when used along with wastewater sludge.

\section{Acknowledgements}

The ANR (French national research agency) is acknowledged for its financial contribution within a larger project entitled ESPACE, which is currently being carried out in partnership with Suez-Environment and IMFT (French public research centre on fluid mechanics).

\section{References}

AFNOR, 1985. NF U 44-160 - Amendements organiques et supports de culture Détermination de la matière organique totale - Méthode par calcination.

AFNOR, 2000. NF EN 13342 - Caractérisation des boues - Dosage de l'azote Kjeldahl. AFNOR, 2001a. NF EN 13137 - Caractérisation des déchets - Dosage du carbone organique total (COT) dans les déchets, boues et sédiments.

AFNOR, 2001b. NF T 90-101 - Qualité de l'eau - Détermination de la demande chimique en oxygène (DCO).

Agnew, J. M., Leonard, J. J., 2003. Physical properties of compost - a review. Compost Science and Utilization 11, 138-264.

Aguilar-Juarez, O., 2000. Analyse et modélisation des réactions biologiques aérobies au cours de la phase d'exploitation d'un casier d'un centre d'enfouissement technique. PhD Thesis. Institut National des Sciences Appliquées de Toulouse. 
Ahn, H., Richard, T., Glanville, T., 2008. Optimum moisture levels for biodegradation of mortality composting envelope materials. Waste Management 28, 1411-1416.

Barrington, S., D. Choinière, M. Trigui and W. Knight. 2002. Compost air flow resistance.

J. Agricultural Engineering Research.81 (4): 433-441.

Coulson, J., Richardson, J., 1994. Chemical and biochemical reactors and process control. Elsevier Science, Oxford.

de Guardia, A., Petiot, C., Rogeau, D., 2008. Influence of aeration rate and biodegradability fractionation on composting kinetics. Waste Management 28, 73-84.

Eftoda, G., McCartney, D., 2004. Determining the critical bulking agent requirement for municipal biosolids composting. COMPOST SCIENCE \& UTILIZATION 12, 208218.

Gea, T., Barrena, R., Artola, A., Sanchez, A., 2007. Optimal bulking agent particle size and usage for heat retention and disinfection in domestic wastewater sludge composting. Waste Management 27, 1108-1116.

Goupy, J., 1999. Plans d'expérience pour surfaces de réponse. Dunod, Paris.

Haug, R., 1993. The practical handbook of compost engineering. Lewis Publishers, Boca Raton, Florida.

Kraft, E., 2002. Methods for determining physical, particle-related characteristics relevant to fluid flow phenomena in biowaste. Bioprocessing of solid waste and sludge 2, 8-16.

Levenspiel, O., 1999. Chemical reaction engineering. John Wiley and Sons, New York.

Liang, C., Das, K. C., McClendon, R. W., 2003. The influence of temperature and moisture contents regimes on the aerobic microbial activity of a biosolids composting blend. Bioresource Technology 86, 131-137. 
Miller, F. C., 1991. Biodegradation of solid wastes by composting. Elsevier Science Publishers Ltd, London.

Mohee, R., Mudhoo, A., 2005. Analysis of the physical properties of an in-vessel composting matrix. Powder Technology 155, 92-99.

Parlement européen, Conseil (2006). Directive 2006/12/CE du Parlement européen et du Conseil du 5 avril 2006 relative aux déchets. Journal officiel de l'Union européenne. L114: 9-21.

Richard, T. L., Hamelers, H. V. M., Veeken, A., Silva, T., 2002. Moisture relationships in composting processes. Compost Science \& Utilization 10, 286-302.

Tremier, A., De Guardia, A., Massiani, C., Martel, J. L., 2005. Influence of the airflow rate on heat and mass transfers during sewage sludge and bulking agent composting. Environmental Technology 26, 1137-1149.

Veeken, A., Timmermans, J., Szanto, G., Hamelers, B. 2003. Design of passively aerated compost systems on basis of consolidation-porosity-permeability data. ORBIT Conference, Perth, Australia.

Yue, B., Chen, T., Gao, G., Zheng, G., Liu, B., Lee, D., 2008. Pile settlement and volume reduction measurement during forced-aeration static composting. Bioresource Technology 99, 7450-7457. 
Table 1. Experimental design, with values normalized based on the Central Composite Factor Design method.

\begin{tabular}{|c|c|c|c|c|c|c|c|c|}
\hline \multirow{3}{*}{ Trial } & \multicolumn{4}{|c|}{ Real values } & \multicolumn{4}{|c|}{ Normalized values } \\
\hline & \multicolumn{3}{|c|}{$\mathrm{MC}(\%)$} & \multirow{2}{*}{$\begin{array}{c}\text { BA psd } \\
(\mathrm{mm})\end{array}$} & \multirow[b]{2}{*}{ Nom. } & \multicolumn{2}{|l|}{$\mathrm{MC}(\%)$} & \multirow{2}{*}{$\begin{array}{c}\text { BA psd } \\
(\mathrm{mm})\end{array}$} \\
\hline & Nom. & $\begin{array}{c}\text { Actual } \\
\text { M1 }\end{array}$ & $\begin{array}{c}\text { Actual } \\
\text { M2 }\end{array}$ & & & $\begin{array}{c}\text { Actual } \\
\text { M1 }\end{array}$ & $\begin{array}{c}\text { Actual } \\
\text { M2 }\end{array}$ & \\
\hline 1 & 45 & 52 & 47.5 & $20-30$ & 0 & 0.389 & 0.139 & 0 \\
\hline 2 & 45 & 51.8 & 45.1 & $8-12$ & 0 & 0.378 & 0.006 & -1.414 \\
\hline 3 & 63 & 63.1 & 61.4 & $12-20$ & 1 & 0.906 & 0.911 & -1 \\
\hline 4 & 27 & 25.1 & 25.8 & $30-40$ & -1 & -1.106 & -1.067 & 1 \\
\hline 5 & 45 & 39.8 & 43.6 & $>40$ & 0 & -0.289 & -0.078 & 1.414 \\
\hline 6 & 27 & 34.7 & 26.5 & $12-20$ & -1 & -0.572 & -1.028 & -1 \\
\hline 7 & 63 & 60.6 & 60.2 & $30-40$ & 0 & 0.867 & 0.844 & 1 \\
\hline 8 & 20 & 24.3 & 25.5 & $20-30$ & -1.414 & -1.150 & -1.083 & 0 \\
\hline 9 & 45 & 44.5 & 43.4 & $20-30$ & 0 & -0.028 & -0.089 & 0 \\
\hline 10 & 70 & 63.3 & 61.4 & $20-30$ & 1.414 & 1.017 & 0.911 & 0 \\
\hline
\end{tabular}

Note: MC- moisture content; BA psd - BA particle size distribution; Nom. - nominal moisture content; $\mathrm{M} 1$ and $\mathrm{M} 2$ - compost recipes using respectively bulking agent BA1 (recycled green waste residues) and bulking agent BA2 (crushed wood pallets). 
Table 2. Characterization of the experimental materials.

\begin{tabular}{|c|c|c|c|c|c|}
\hline Parameter & Sludge & BA 1 & BA 2 & M1 & M2 \\
\hline $\mathrm{OM}$ & 81.1 & 91.9 & 99.0 & 87.4 & 97.0 \\
\hline$(\%)$ & $(2.8)$ & $(2.0)$ & $(0.5)$ & (5.4) & $(0.6)$ \\
\hline COD & 1406 & 1398 & 1353 & 1384 & 1322 \\
\hline$\left(\mathrm{mg} \mathrm{O}_{2} \mathrm{~g} \mathrm{DM}^{-1}\right)$ & (7.4) & $(5.4)$ & (2.1) & $(6.1)$ & $(4.0)$ \\
\hline $\mathrm{TC}$ & 488.3 & 506.9 & 482.8 & 483.2 & 495.3 \\
\hline$\left(\mathrm{mg} \mathrm{C} \mathrm{g} \mathrm{DM}^{-1}\right)$ & $(6.1)$ & $(2.4)$ & $(1.8)$ & (5.8) & $(4.5)$ \\
\hline TKN & 44.5 & 4.6 & 11.0 & 36.2 & 14.0 \\
\hline$\left(\mathrm{mg} \mathrm{N} \mathrm{g} \mathrm{DM}^{-1}\right)$ & $(6.8)$ & $(23.5)$ & $(44.2)$ & $(36.2)$ & $(25.4)$ \\
\hline $\mathrm{OM} / \mathrm{TC}$ ratio & 1.66 & 1.81 & 2.05 & 1.81 & 1.96 \\
\hline
\end{tabular}

Note: BA1 and BA 2 - bulking agents 1 (recycled green waste residues) and bulking agent 2 (crushed wood pallets), respectively; M1 and M2 - compost recipe mixtures using respectively bulking agents 1 and 2; values in parenthesis - coefficients of variation, $\mathrm{CV}(\%)$; OM - organic matter; COD - Chemical Oxygen Demand; TC Total Carbon, and; TKN - Total Kjeldahl Nitrogen. 
Table 3. Oxygen uptake, consolidation and air initial dispersion coefficients for all trials.

\begin{tabular}{ccccccc}
\hline Trial & $\begin{array}{c}\text { Total } \mathrm{O}_{2} \text { uptake } \\
\left(\mathrm{Mole} \mathrm{O}_{2} \mathrm{~kg} \mathrm{DM}^{-1}\right)\end{array}$ & $\begin{array}{c}\text { Consolidation } \\
(\% \text { initial height })\end{array}$ & $\begin{array}{c}\text { Airflow dispersion } \\
\text { coefficient } \\
\left(\mathrm{D}^{\prime}, \mathrm{m}^{2} \mathrm{~s}^{-1}\right)\end{array}$ \\
\cline { 2 - 7 } & $\mathrm{M} 1$ & $\mathrm{M} 2$ & $\mathrm{M} 1$ & $\mathrm{M} 2$ & $\mathrm{M} 1$ & $\mathrm{M} 2$ \\
\hline 1 & 8.71 & 6.3 & 13 & 7.9 & $5.1910^{-4}$ & $43.210^{-4}$ \\
3 & 10.50 & 6.3 & 15 & 5.6 & $1.2310^{-4}$ & $2.4710^{-4}$ \\
4 & 6.00 & 7.6 & 9.7 & 6.1 & $4.1510^{-4}$ & $13010^{-4}$ \\
5 & 3.46 & 1.6 & 0.4 & 0 & $13.410^{-4}$ & $10410^{-4}$ \\
6 & 6.69 & 4.7 & 3 & 0 & $3.4710^{-4}$ & $47410^{-4}$ \\
7 & 5.21 & 7.8 & 1.3 & 2.5 & $2.2810^{-4}$ & $3.7010^{-4}$ \\
8 & 7.19 & 6.5 & 3.7 & 7.4 & $2.5910^{-4}$ & $11.210^{-4}$ \\
9 & 3.83 & 2.1 & 2.2 & 1.7 & $10.210^{-4}$ & $1.8410^{-4}$ \\
10 & 7.12 & 4.7 & 9.7 & 5.8 & $3.4010^{-4}$ & $336010^{-4}$ \\
\hline 3.11 & 4.4 & 7.6 & 3.2 & $\mathrm{ND}^{-4}$ & $3.9210^{-4}$ \\
\hline
\end{tabular}

Note: M1 and M2 - compost recipe mixtures using respectively bulking agents 1 and 2;

ND - data not available. 
Table 4. Significant effect of independent variables X1 (moisture content) and X2 (bulking agent particle size distribution).

\begin{tabular}{|c|c|c|c|c|c|}
\hline \multirow{2}{*}{$\begin{array}{l}\text { Predictive } \\
\text { response }\end{array}$} & \multirow[t]{2}{*}{ Term } & \multicolumn{2}{|c|}{ M1 } & \multicolumn{2}{|c|}{ M2 } \\
\hline & & Coefficient & $\mathrm{p}$ - value & Coefficient & $\mathrm{p}$ - value \\
\hline \multirow{3}{*}{$\begin{array}{c}\text { Total } \mathrm{O}_{2} \text { uptake } \\
\left(\text { Mole } \mathrm{O}_{2} \mathrm{~kg} \mathrm{DM}^{-1}\right)\end{array}$} & Intercept & 8.32 & - & 5.521 & - \\
\hline & $\mathrm{X}_{1}$ & - & - & 1.978 & 0.0085 \\
\hline & $\mathrm{X}_{11}$ & -3.62 & 0.0089 & -1.371 & 0.1259 \\
\hline \multirow{6}{*}{$\begin{array}{c}\text { Consolidation } \\
\text { (\% of initial height) }\end{array}$} & Intercept & 10.94 & - & 4.13 & - \\
\hline & $\mathrm{X}_{1}$ & 2.71 & 0.1091 & 2.23 & 0.0557 \\
\hline & $\mathrm{X}_{2}$ & -2.21 & 0.1179 & -1.08 & 0.2334 \\
\hline & $\mathrm{X}_{11}$ & -5.98 & 0.0574 & - & - \\
\hline & $X_{12}$ & -4.86 & 0.0567 & - & - \\
\hline & $X_{22}$ & -2.59 & 0.1471 & - & - \\
\hline \multirow{7}{*}{$\begin{array}{l}\text { Airflow dispersion } \\
\text { coefficient } \\
\left(D^{\prime}, \mathrm{m}^{2} \mathrm{~s}^{-1}\right)\end{array}$} & Intercept & $4.1410^{-4}$ & - & 0.149 & - \\
\hline & & & & & \\
\hline & $\mathrm{X}_{1}$ & $-1.7810^{-4}$ & 0.0724 & - & - \\
\hline & $\mathrm{X}_{2}$ & $1.0310^{-4}$ & 0.1164 & - & - \\
\hline & $\mathrm{X}_{11}$ & $3.4410^{-4}$ & 0.0430 & -0.111 & 0.1281 \\
\hline & $\mathrm{X}_{12}$ & $-2.5510^{-4}$ & 0.0457 & - & - \\
\hline & $X_{22}$ & $-1.6210^{-4}$ & 0.0834 & -0.055 & 0.2279 \\
\hline
\end{tabular}

Note: M1 and M2 - compost recipe mixtures using respectively bulking agents 1 and 2. 
Table 5a. ANOVA for M1 compost recipes using sludge and bulking agent 1 (recycled green waste residues).

\begin{tabular}{|c|c|c|c|c|c|c|}
\hline \multirow{2}{*}{ Predictive response } & \multicolumn{6}{|l|}{ M1 } \\
\hline & Source & Sum & D.F. & F value & $\mathrm{P}$ value & $\mathrm{R}^{2}$ \\
\hline \multirow{4}{*}{$\begin{array}{l}\text { Total } \mathrm{O}_{2} \text { uptake } \\
\left(\text { Mole } \mathrm{O}_{2} \mathrm{~kg} \mathrm{DM}^{-1}\right)\end{array}$} & $\overline{\text { Model }}$ & 29.3 & 1 & 11.77 & 0.73 & 60 \\
\hline & Residual & 20.3 & 8 & & & \\
\hline & Total & 59.9 & 9 & & & \\
\hline & Model & 234.6 & 5 & 5.17 & 0.68 & 87 \\
\hline \multirow{2}{*}{$\begin{array}{l}\text { Consolidation } \\
\text { (\% of initial height) }\end{array}$} & Residual & 36.3 & 4 & & & \\
\hline & Total & 270.9 & 9 & & & \\
\hline Airflow dispersion & Model & $1.2610^{-6}$ & 5 & 15.7 & 0.023 & 96 \\
\hline coefficient & Residual & $0.0410^{-6}$ & 3 & & & \\
\hline$\left(D^{\prime}, m^{2} s^{-1}\right)$ & Total & $1.310^{-6}$ & 8 & & & \\
\hline
\end{tabular}


Table 5b. ANOVA for M2 compost recipes using sludge and bulking agent 2 (crushed wood pallets).

\begin{tabular}{|c|c|c|c|c|c|c|}
\hline \multirow{2}{*}{ Predictive response } & \multicolumn{6}{|l|}{ M2 } \\
\hline & Source & Sum & D.F. & F value & $\mathrm{P}$ value & $\mathrm{R}^{2}$ \\
\hline \multirow{4}{*}{$\begin{array}{l}\text { Total } \mathrm{O}_{2} \text { uptake } \\
\left(\text { Mole } \mathrm{O}_{2} \mathrm{~kg} \mathrm{DM}^{-1}\right)\end{array}$} & Model & 25.7 & 2 & 10.78 & 0.01 & 78 \\
\hline & Residual & 7.1 & 6 & & & \\
\hline & Total & 32.8 & 8 & & & \\
\hline & Model & 39.0 & 2 & 3.58 & 0.085 & 51 \\
\hline \multirow{2}{*}{$\begin{array}{l}\text { Consolidation } \\
\text { (\% of initial height) }\end{array}$} & Residual & 38.1 & 7 & & & \\
\hline & Total & 77.1 & 9 & & & \\
\hline Airflow dispersion & Model & 0.03 & 2 & 1.92 & 0.216 & 35 \\
\hline coefficient & Residual & 0.06 & 7 & & & \\
\hline$\left(D^{\prime}, m^{2} s^{-1}\right)$ & Total & 0.09 & 9 & & & \\
\hline
\end{tabular}




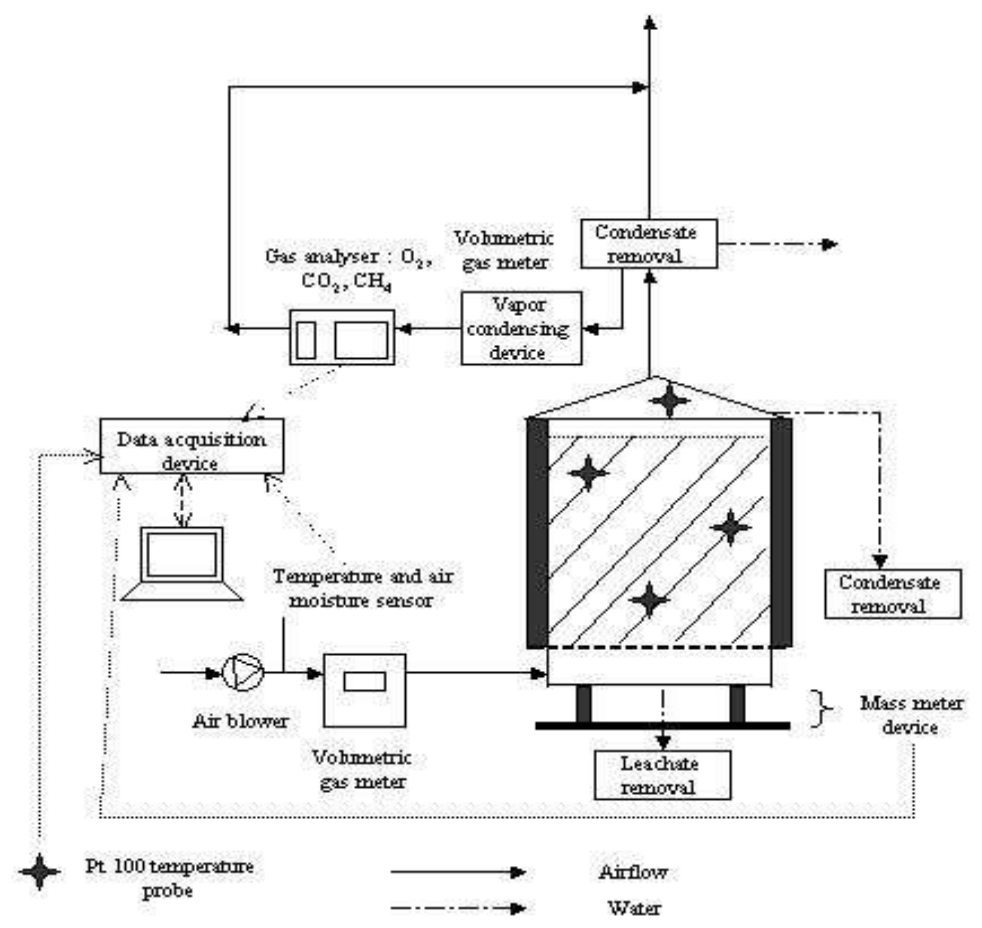

Figure 1. Set-up used for each one of the three experimental composting pilot reactor. 


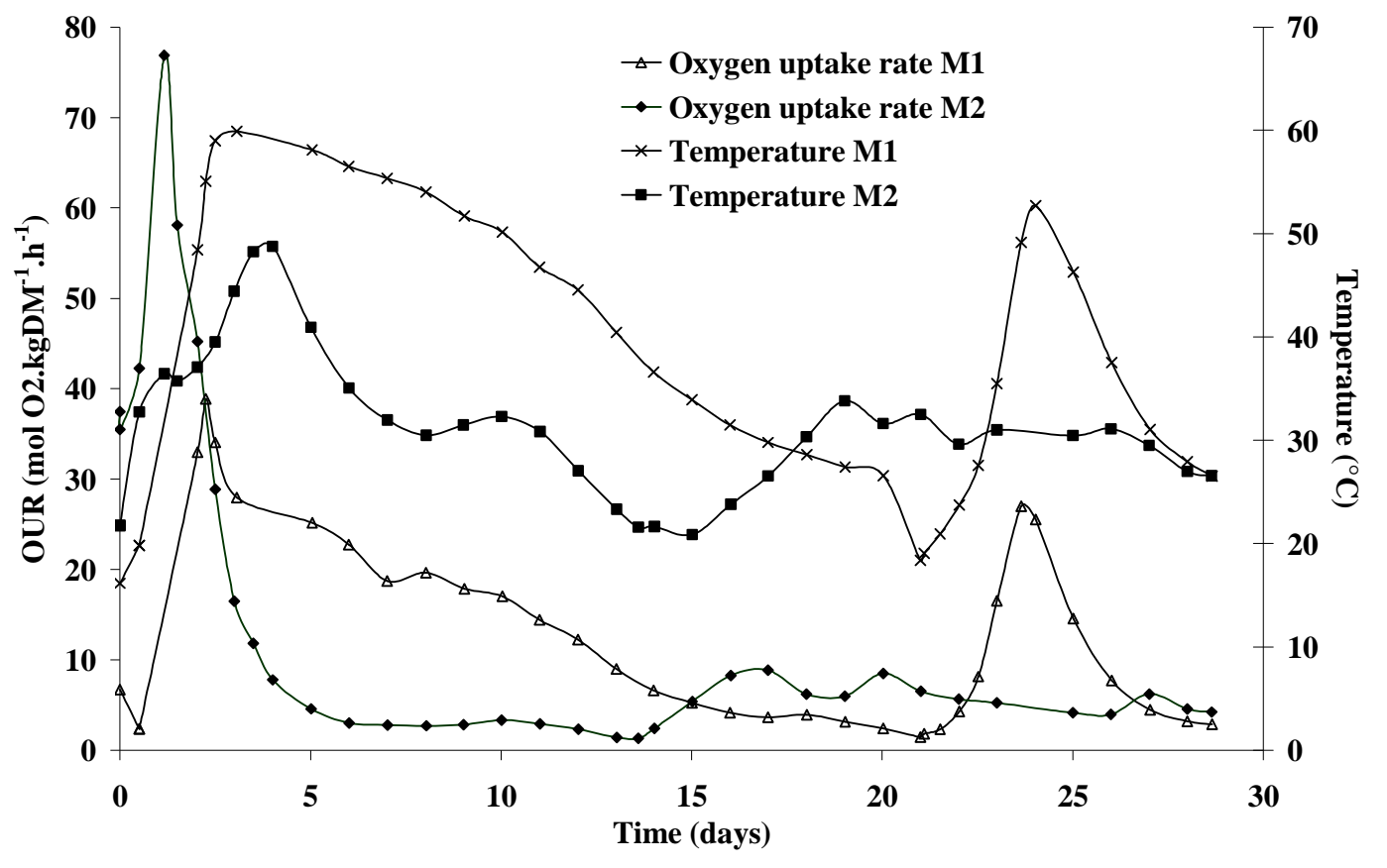

Figure 2. Variation in $\mathrm{O}_{2}$ uptake rate and temperature for M1 and M2 mixtures, using respectively bulking agent BA1 (recycled green waste residues) and bulking agent BA2 (crushed wood pallets). 


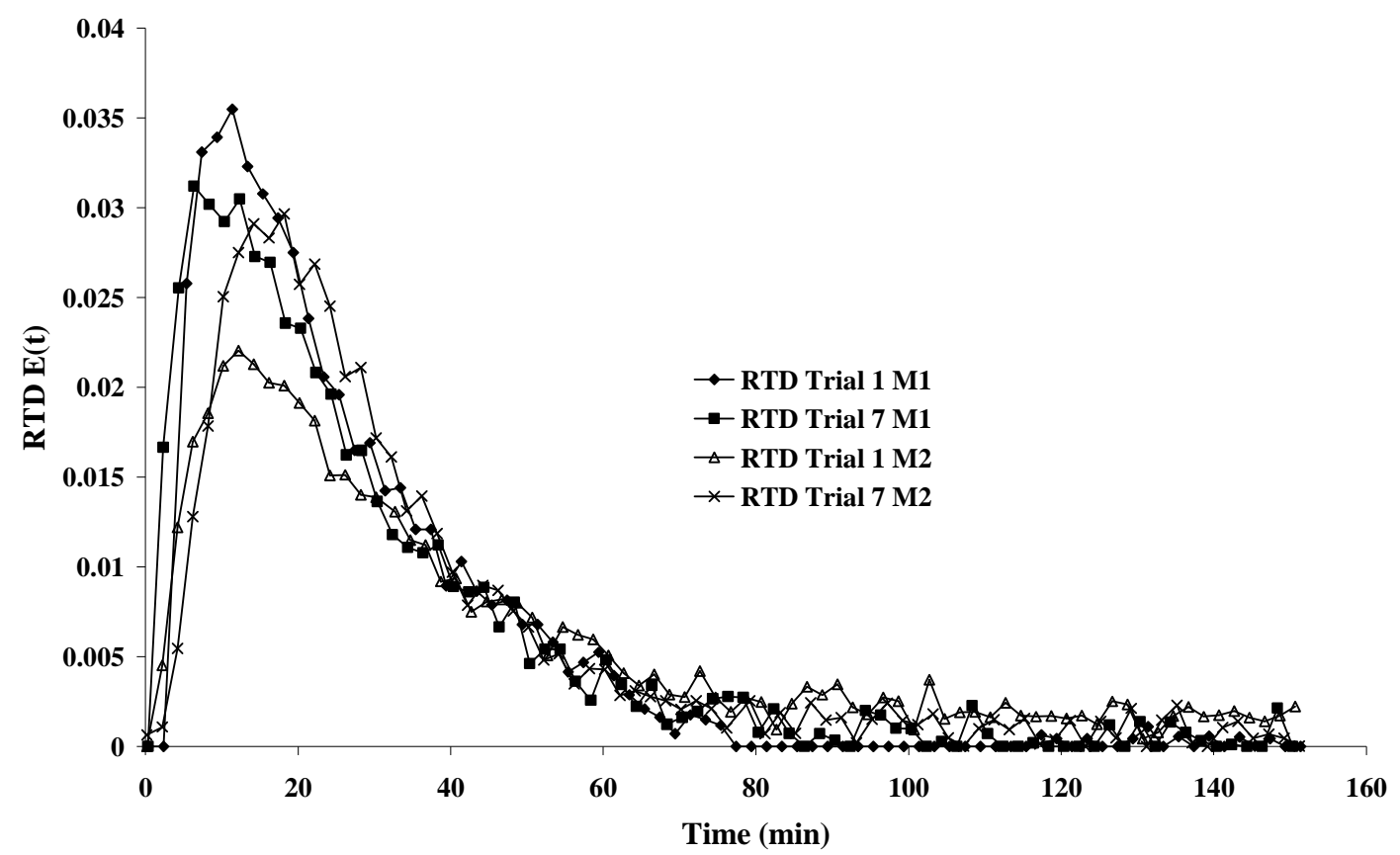

Figure 3. Examples of Retention Time Distribution (RTD) curves during the initial phases of composting for M1 and M2 mixtures, using respectively bulking agent BA1 (recycled green waste residues) and bulking agent BA2 (crushed wood pallets). 


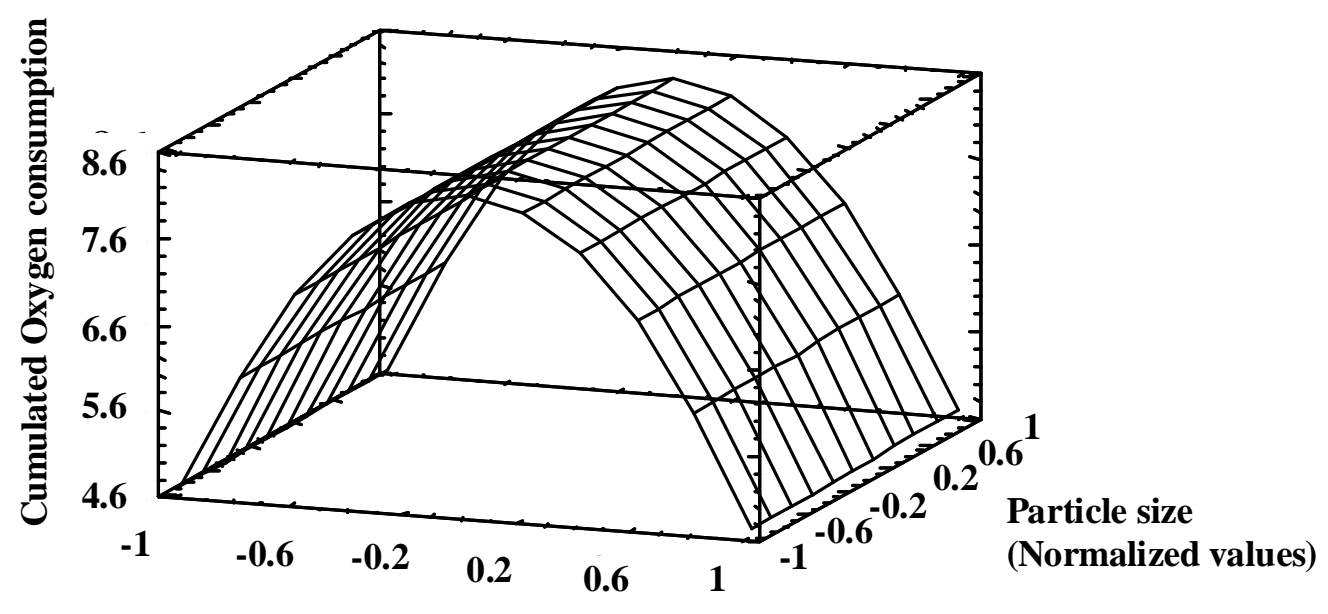

Moisture (Normalized values)

Figure 4. Estimated $\mathrm{O}_{2}$ uptake surface response curve for M1 mixtures using bulking agent BA1 (recycled green waste residues). 


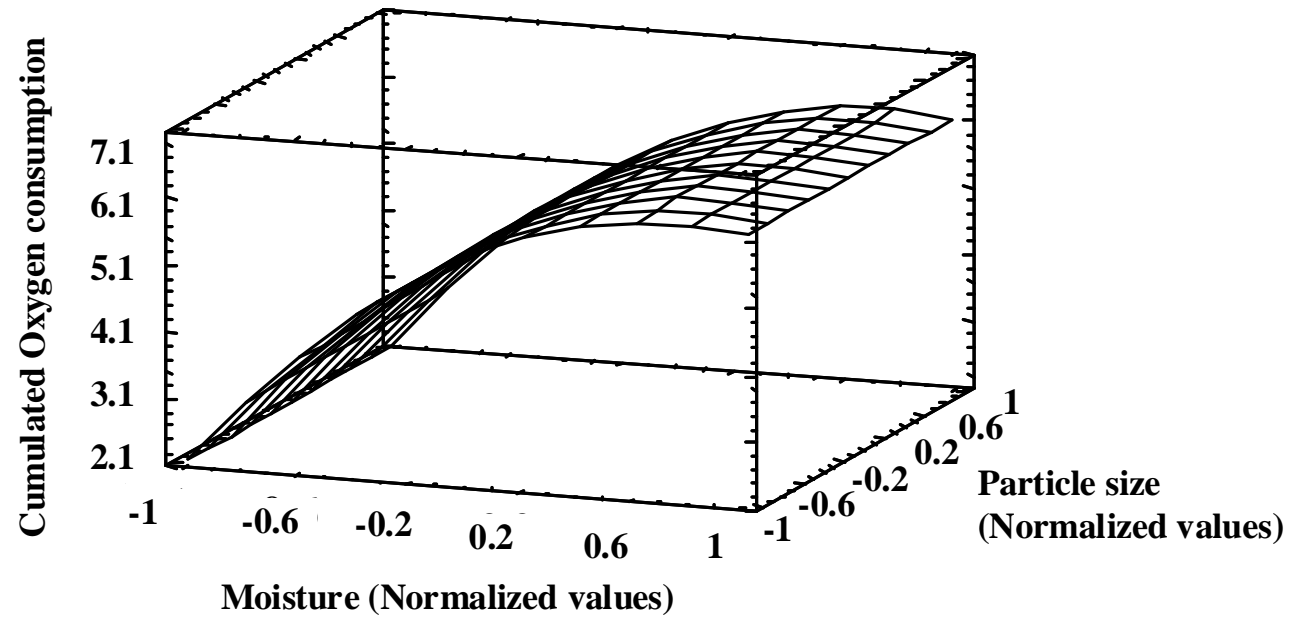

Figure 5. Estimated $\mathrm{O}_{2}$ uptake surface response curve for $\mathrm{M} 2$ mixtures using bulking agent BA2 (crushed wood pallets). 


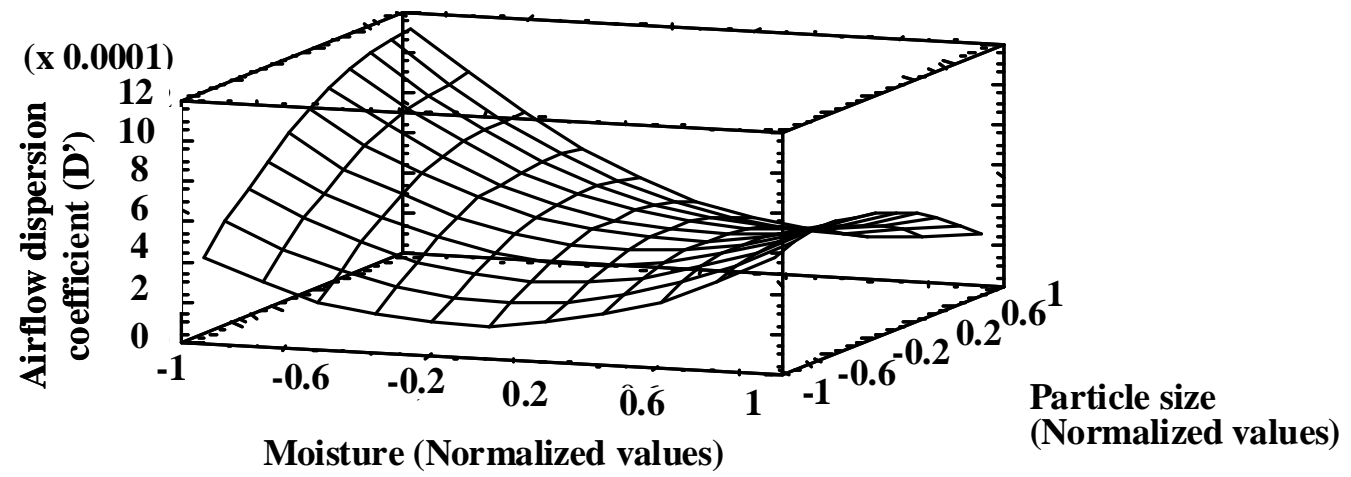

Figure 6. Estimated surface response curve for initial airflow dispersion coefficient using M1 mixtures consisting of sludge and bulking agent BA1 (recycled green waste). 